\title{
A Study of Synthesis of Cerium-Doped Yttrium Silicate and Yttrium Disilicate Phosphors by the Ammonia-Added Sol-Gel Method*
}

\author{
Le Xuan Thanh ${ }^{\dagger}$ \\ Department of Technology of Inorganic Compounds, \\ Hanoi University of Technology, Hanoi, Vietnam \\ Phung Thi Mai Phuong \\ Vietnam Institute of Industrial Chemistry, Hanoi, Vietnam \\ (Received 5 December 2009; Accepted 13 May 2010; Published 23 June 2012)
}

\begin{abstract}
Pure-phase cerium-doped yttrium silicate and yttrium disilicate phosphors were successfully synthesized by the sol-gel method with added ammonia when the precursor was calcined at $1100^{\circ} \mathrm{C}$ and $1300^{\circ} \mathrm{C}$ for $1 \mathrm{~h}$. The blue light was emitted when excited by the UV radiation of $325 \mathrm{~nm}$ wavelength. The luminescence of $\mathrm{Y}_{2} \mathrm{SiO}_{5}: \mathrm{Ce}_{1} \%$ phosphors was less than that of $\mathrm{Y}_{2} \mathrm{Si}_{2} \mathrm{O}_{7}$ : Ce1\% in the same synthetic condition. Besides, their photoluminescence was strongly increased when $\mathrm{Li}, \mathrm{Na}$ or $\mathrm{K}$ sensitizers were added. The $\mathrm{X}_{1}-\mathrm{Y}_{2} \mathrm{SiO}_{5}$ and $\mathrm{X}_{2}-\mathrm{Y}_{2} \mathrm{SiO}_{5}$ phosphors were irregular shapes and composed of agglomerates with the particle size of approximately $70 \mathrm{~nm}$ to $100 \mathrm{~nm}$. [DOI: $10.1380 /$ ejssnt.2012.248]
\end{abstract}

Keywords: Phosphors; Photoluminescence; Cerium; $\mathrm{Y}_{2} \mathrm{SiO}_{5} ; \mathrm{Y}_{2} \mathrm{Si}_{2} \mathrm{O}_{7}$

\section{INTRODUCTION}

Phosphors usually contain activator ions in addition to the host material. These ions are deliberately added in a proper proportion in the process. Activator ions chosen from the rare-earth elements are ideal for providing narrow emission bands in the selected wavelength regions due to their many optical transitions. With suitable hosts, $\mathrm{Eu}^{3+}$ emits red-orange radiation from ${ }^{5} \mathrm{D}_{0}-\mathrm{F}_{2}$ transition, used for red emission; the $\mathrm{Tb}^{3+}$ with ${ }^{5} \mathrm{D}_{4}-\mathrm{F}_{4}$ transition is used for green one; and divalent europium, $\mathrm{Eu}^{2+}$ and $\mathrm{Ce}^{3+}, d-f$ for blue band. Europium, terbium, and cerium are of industrial interest as activators. The sensitizer, which is an activator ion itself, absorbs exciting radiation and transfers the energy to primary activators. The activators and their surrounding ions form the active optical centers.

Oxygen-dominant phosphors have been well recognized because of their good temperature stability as well as higher quantum yields. Yttrium silicate $\mathrm{Y}_{2} \mathrm{SiO}_{5}: \mathrm{Ce}^{3+}$ is used as a highly resistant blue cathode-ray phosphor in projection television tubes $[1,2]$ and is considered a potential candidate for replacement of $\mathrm{ZnS}: \mathrm{Ag}$ as being the blue phosphor for FEDs [3]. In addition, yttrium silicate is itself also used as high-temperature protective coatings for silicon carbide composites reinforced with carbon fibres, used in aerospace application [4]. Recently, there have been a number of studies on the synthesis of yttrium silicate doped by europium or cerium $[2,5-12]$. However, synthesized phosphors often contained unreacted $\mathrm{Y}_{2} \mathrm{O}_{3} / \mathrm{SiO}_{2}$ constituents or additional silicate/disilicate phases [5-9], possibly creating negative effects on luminescent properties. The phase purity is of importance

\footnotetext{
* This paper was presented at the International Workshop on Advanced Materials and Nanotechnology 2009 (IWAMN2009), Hanoi University of Science, VNU, Hanoi, Vietnam, 24-25 November, 2009. ${ }^{\dagger}$ Corresponding author: xuanthanhle69@yahoo.com
}

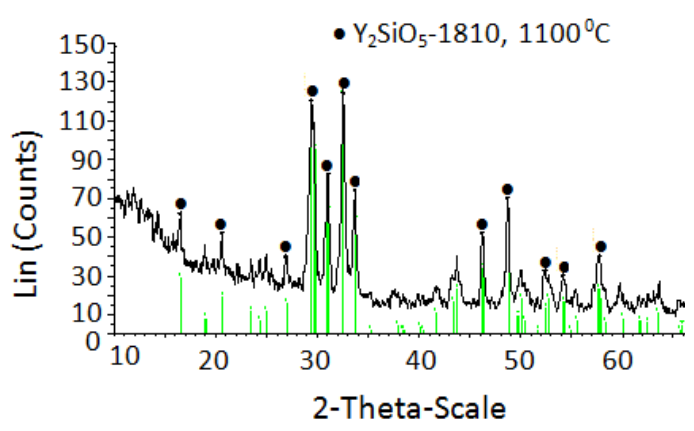

FIG. 1: X-ray diffraction pattern of $\mathrm{Y}_{2} \mathrm{SiO}_{5}: \mathrm{Ce} 1 \%$ calcined at $1100^{\circ} \mathrm{C}$.

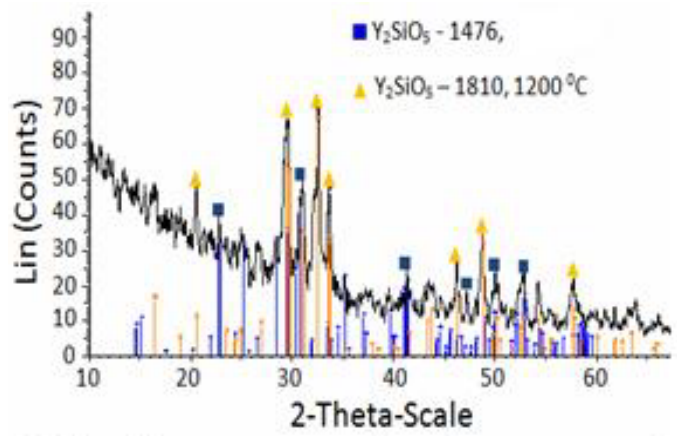

FIG. 2: X-ray diffraction pattern of $\mathrm{Y}_{2} \mathrm{SiO}_{5}: \mathrm{Ce} 1 \%$ calcined at $1200^{\circ} \mathrm{C}$.

in the preparation of phosphors with high luminescence. Thus, further researches on the synthesis of phosphors are certainly on demand. The aim of this research is the synthesis of pure-phase $\mathrm{Y}_{2} \mathrm{SiO}_{5}$ and $\mathrm{Y}_{2} \mathrm{Si}_{2} \mathrm{O}_{7}$ phosphors doped by cerium, either contain or not have $\mathrm{Li}, \mathrm{Na}$ and $\mathrm{K}$ sensitizers via the sol-gel method with added ammonia. 


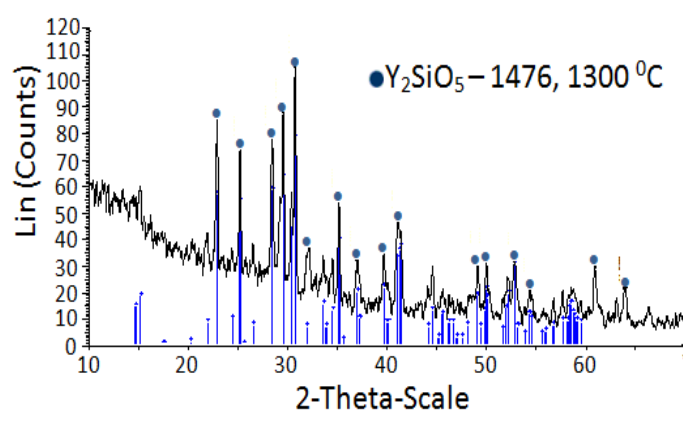

FIG. 3: X-ray diffraction pattern of $\mathrm{Y}_{2} \mathrm{SiO}_{5}: \mathrm{Ce} 1 \%$ calcined at $1300^{\circ} \mathrm{C}$.

TABLE I: Lattice parameters $a, b$ and $c$ and the angles between the edges of unit cells of obtained samples.

\begin{tabular}{lll}
\hline \hline Sample & $\begin{array}{l}\text { Lattice parameters } \\
(\AA)\end{array}$ & $\begin{array}{l}\text { Angles } \\
\text { (degree) }\end{array}$ \\
\hline $\mathrm{X}_{1}-\mathrm{Y}_{2} \mathrm{SiO}_{5}: \mathrm{Ce} 1 \%$, & $a=9.01390$ & $\alpha=90.000$ \\
monoclinic, & $b=6.92820$ & $\beta=106.680$ \\
calcined at $1100^{\circ} \mathrm{C}$ & $c=6.64270$ & $\gamma=90.000$ \\
\hline $\mathrm{X}_{2}-\mathrm{Y}_{2} \mathrm{SiO}_{5}: \mathrm{Ce} \%$, & $a=12.50130$ & $\alpha=90.000$ \\
monoclinic, & $b=6.72820$ & $\beta=102.682$ \\
calcined at $1300^{\circ} \mathrm{C}$ & $c=10.42170$ & $\gamma=90.000$ \\
\hline \hline
\end{tabular}

\section{EXPERIMENTAL}

\section{A. Materials}

Yttrium nitrate, cerium (III) nitrate and tetraethylorthosilicate (TEOS) are Merck grade. The ammonia, acetate salts of lithium, sodium and potassium and absolute ethanol are AR type.

\section{B. Experimental}

The precursors were prepared from materials with molar ratios for those phosphors to prepare: $\mathrm{Y}_{2} \mathrm{SiO}_{5}: \mathrm{Ce} 1 \%$ and $\mathrm{Y}_{2} \mathrm{Si}_{2} \mathrm{O}_{7}: \mathrm{Ce} 1 \%$. The cerium concentration was 1 mol \% compared to that of yttrium one. Firstly, the $\mathrm{Y}\left(\mathrm{NO}_{3}\right)_{3}$ solution was stirred and subsequently added with $\mathrm{Ce}\left(\mathrm{NO}_{3}\right)_{3}$, ethanol and TEOS to obtain a liquid having the volume ratio of ethanol: water was $2: 1$ and the yttrium concentration was $0.15 \mathrm{M}$. Then, a $25 \%$ ammonia amount was added into the obtained liquid with the volume of $5 \%$ increased compared to the requirement for a complete precipitation of $\mathrm{Y}^{3+}$ and $\mathrm{Ce}^{3+}$ ions. After ammonia was added, a white precipitate was immediately formed and the liquid quickly coagulated into a gel-like mass. The gel-like mass was continuously stirred at room temperature for $24 \mathrm{~h}$, then at $60^{\circ} \mathrm{C}$ for about 16 $\mathrm{h}$ until a white precursor was obtained. The preparation of precursors added with $\mathrm{Li}, \mathrm{Na}$ or $\mathrm{K}$ sensitizers at the concentration of $1 \mathrm{~mol} \%$ compared to that of yttrium was similarly conducted. After being dried at $80^{\circ} \mathrm{C}$, the precursors were slightly ground and calcined in the air at 1100, 1200 and $1300^{\circ} \mathrm{C}$ for $1 \mathrm{~h}$ in the Nebertherm kiln

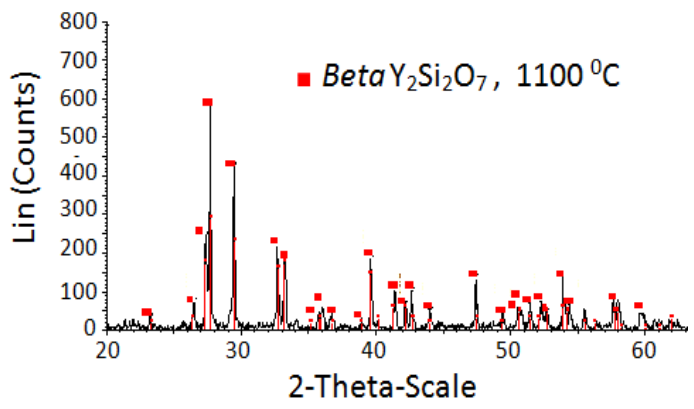

FIG. 4: X-ray diffraction pattern of $\mathrm{Y}_{2} \mathrm{Si}_{2} \mathrm{O}_{7}$ :Ce1\% calcined at $1100^{\circ} \mathrm{C}$.

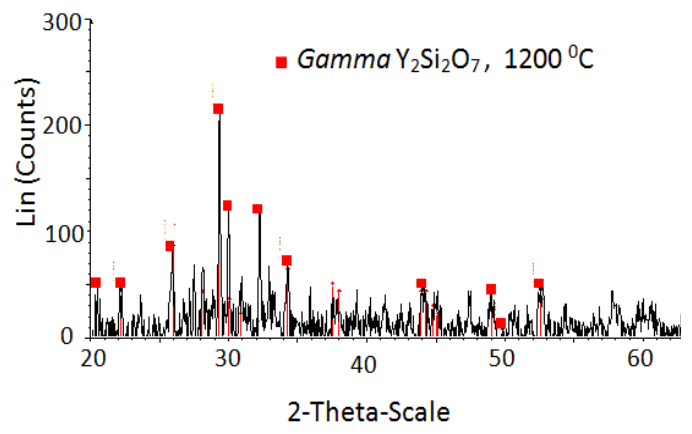

FIG. 5: X-ray diffraction pattern of $\mathrm{Y}_{2} \mathrm{Si}_{2} \mathrm{O}_{7}$ :Ce1\% calcined at $1200^{\circ} \mathrm{C}$.

at a rate of $10^{\circ} \mathrm{C} / \mathrm{min}$. The phase of products was characterized by XRD method via the D8 Advanced Bruker. Their photo-luminescence was measured in the high resolution system using spectrometer iHR550-Synapse CCD, HORIBA Jobin Yvon with the laser source of $325 \mathrm{~nm}$ wavelength and their morphology was taken on the Hitachi SEM S-4800.

\section{RESULTS AND DISCUSSION}

\section{A. X-ray powder diffraction data}

The XRD diagrams of the calcined samples at high temperatures were indicated in Figs. 1-3 for $\mathrm{Y}_{2} \mathrm{SiO}_{5}: \mathrm{Ce} 1 \%$ phosphor. In Figs. 1-3, the sample calcined at $1100^{\circ} \mathrm{C}$ composed of pure $\mathrm{Y}_{2} \mathrm{SiO}_{5}$ phase (JCPDS No. 52-1810), while the sample calcined at $1200^{\circ} \mathrm{C}$ contained $\mathrm{Y}_{2} \mathrm{SiO}_{5}$ (JCPDS No. 52-1810) and $\mathrm{Y}_{2} \mathrm{SiO}_{5}$ (JCPDS No. 36-1476) phases, and the sample calcined at $1300^{\circ} \mathrm{C}$ was of the pure $\mathrm{Y}_{2} \mathrm{SiO}_{5}$ phase (JCPDS No. 36-1476). Results indicated that the obtained yttrium silicate phosphor had two modifications: the $\mathrm{X}_{1}-\mathrm{Y}_{2} \mathrm{SiO}_{5}$ (JCPDS No. 52-1810) formed at $1100^{\circ} \mathrm{C}$ and the $\mathrm{X}_{2}-\mathrm{Y}_{2} \mathrm{SiO}_{5}$ (JCPDS No. 361476 ) formed at $1300^{\circ} \mathrm{C}$. And there was a partial transition of $\mathrm{X}_{1}-\mathrm{Y}_{2} \mathrm{SiO}_{5}$ into $\mathrm{X}_{2}-\mathrm{Y}_{2} \mathrm{SiO}_{5}$ at $1200^{\circ} \mathrm{C}$ during the heating time of $1 \mathrm{~h}$. From the XRD data, all phosphors have monoclinic structure and lattice parameters and angles between the edges of their unit cells are shown in Table I. Based on the lattice parameters, it is clear that the size of the unit cell of the samples increases with the 


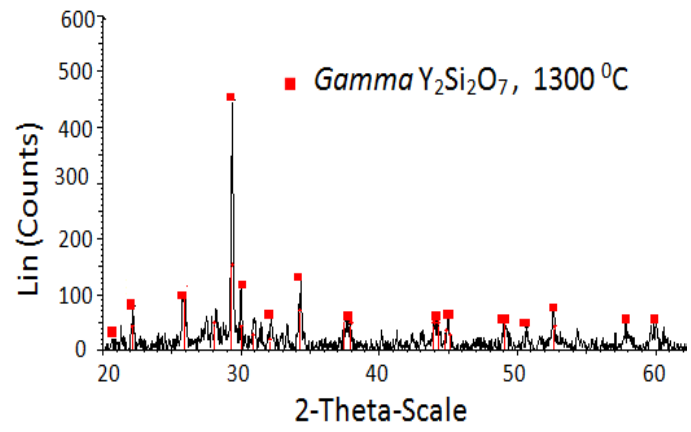

FIG. 6: X-ray diffraction pattern of $\mathrm{Y}_{2} \mathrm{Si}_{2} \mathrm{O}_{7}$ :Ce1\% calcined at $1300^{\circ} \mathrm{C}$.

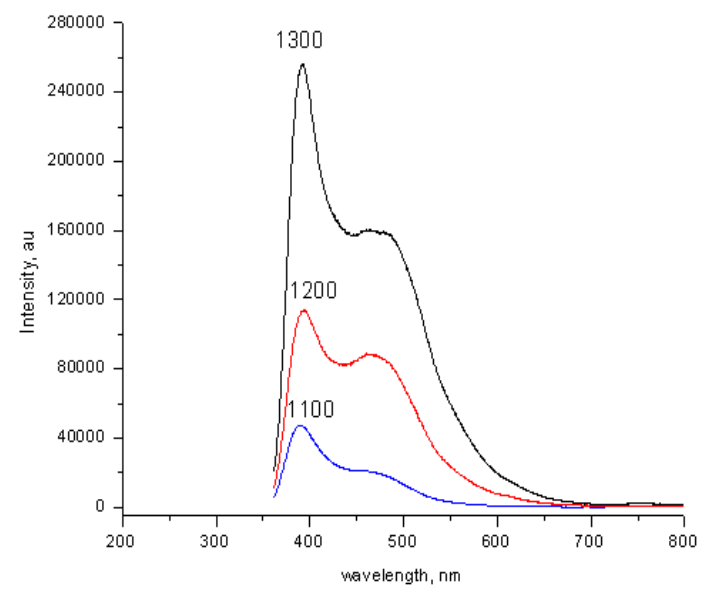

FIG. 7: Photoluminescence spectra of $\mathrm{Y}_{2} \mathrm{SiO}_{5}: \mathrm{Ce} 1 \%$ calcined at 1100,1200 and $1300^{\circ} \mathrm{C}$.

increased temperature. The peaks at XRD diagrams are sharp, indicating that crystal characteristic and average crystal size (if ascertained from the Scherrer equation) of the samples increase with the increased temperature. The formation of pure $\mathrm{X}_{2}-\mathrm{Y}_{2} \mathrm{SiO}_{5}$ phase occured at the lower temperature and shorter calcined time compared to those indicated by [3] - in which, it was up to $1600^{\circ} \mathrm{C}$ in $2 \mathrm{~h}$. In additon, all the annealed samples had white color, proving that $\mathrm{Ce}^{3+}$ ions were stable in the yttrium silicate host (similar to yttrium disilicate) at the examined condition, making these silicates available for high-temperature protective coatings.

XRD diagrams of the calcined samples for $\mathrm{Y}_{2} \mathrm{Si}_{2} \mathrm{O}_{7}$ :Ce1\% phosphor were indicated in Figs. 46. It has been shown that the sample calcined at $1100^{\circ} \mathrm{C}$ composed of only beta- $\mathrm{Y}_{2} \mathrm{Si}_{2} \mathrm{O}_{7}$ phase (JCPDS No. 211454) with monoclinic structure, while samples calcined at $1200^{\circ} \mathrm{C}$ contained the gamma phase and at $1300^{\circ} \mathrm{C}$ composed of unique gamma- $\mathrm{Y}_{2} \mathrm{Si}_{2} \mathrm{O}_{7}$ phase (JCPDS No 32-1448).

\section{B. Photoluminescence}

The $\mathrm{Ce}^{3+}$ ion has one $4 f$ electron and its lowest excited configuration is $5 d^{1}$. In Fig. 7, it shows the photoluminescence (PL) spectra of $\mathrm{Y}_{2} \mathrm{SiO}_{5}: \mathrm{Ce} 1 \%$ calcined at 1100,1200

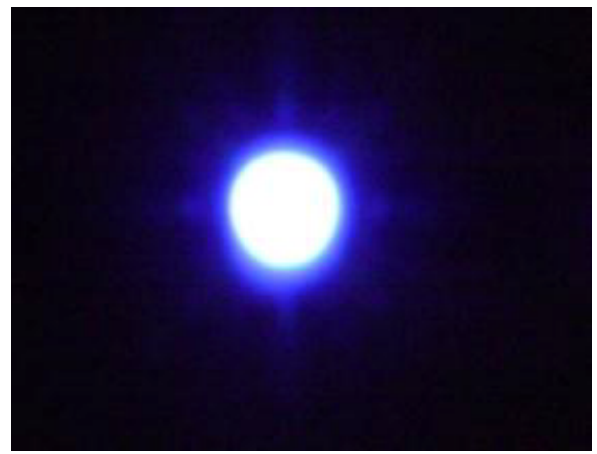

FIG. 8: Photoluminescence image of $\mathrm{Y}_{2} \mathrm{SiO}_{5}: \mathrm{Ce} 1 \%$ calcined $1300^{\circ} \mathrm{C}$.

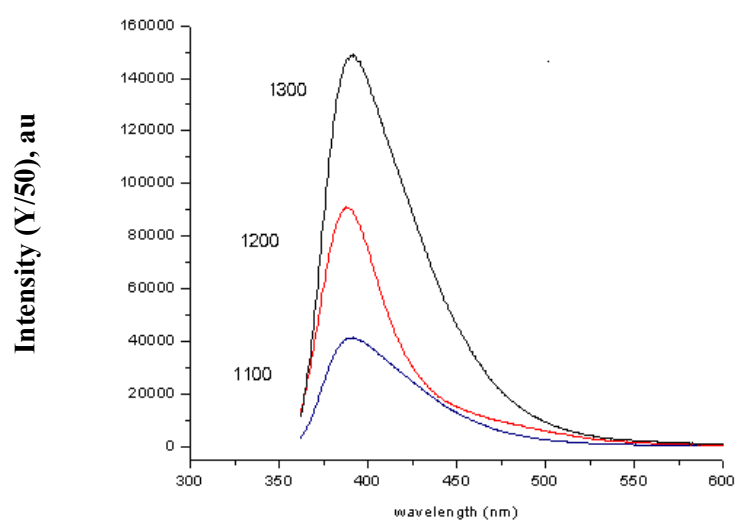

FIG. 9: Photoluminescence spectra of $\mathrm{Y}_{2} \mathrm{Si}_{2} \mathrm{O}_{7}$ :Ce1\% calcined at 1100,1200 and $1300^{\circ} \mathrm{C}$ (Y-Intensity).

and $1300^{\circ} \mathrm{C}$ when being excited by UV radiation of 325 $\mathrm{nm}$ wavelength. The spectral curves are the same for all samples and indicate two $5 d^{1} \rightarrow 4 f^{1}$ emission bands with maxima at $390 \mathrm{~nm}$ (stronger) and at $470 \mathrm{~nm}$ (weaker) for the blue. The PL intensity remarkably increases with the calcined temperature because of the stronger crystal feature of the obtained phosphor. The $\mathrm{Y}_{2} \mathrm{SiO}_{5}: \mathrm{Ce} 1 \%$ calcined at $1300^{\circ} \mathrm{C}$ under $\mathrm{UV}$ radiation of $325 \mathrm{~nm}$ wavelength $\left(\mathrm{X} 2-\mathrm{Y}_{2} \mathrm{SiO}_{5}\right)$ has the highest $\mathrm{PL}$ intensity and the digital image is shown in Fig. 8.

It is interesting that the intensity of $\mathrm{Y}_{2} \mathrm{Si}_{2} \mathrm{O}_{7}: \mathrm{Ce} 1 \%$ phosphors calcined at 1100,1200 and $1300^{\circ} \mathrm{C}$ is higher than that of $\mathrm{Y}_{2} \mathrm{SiO}_{5}$ :Ce1\% when being excited by UV radiation of $325 \mathrm{~nm}$ wavelength. (Fig. 9). In addition, only the strong $5 d^{1} \rightarrow 4 f^{1}$ emission band of the $\mathrm{Ce}^{3+}$ ion under UV excitation is observed at $390 \mathrm{~nm}$ for the blue emission. The PL intensity considerably increases when it transfers from the beta- $\mathrm{Y}_{2} \mathrm{Si}_{2} \mathrm{O}_{7}$ to the gamma- $\mathrm{Y}_{2} \mathrm{Si}_{2} \mathrm{O}_{7}$.

\section{Sensitizers}

The $\mathrm{Li}^{+}, \mathrm{Na}^{+}$and $\mathrm{K}^{+}$ions are typical sensitizers. Their influence on PL intensity of the $\mathrm{X}_{2}-\mathrm{Y}_{2} \mathrm{SiO}_{5}$ phosphor is indicated in Fig. 10. All $\mathrm{X}_{2}-\mathrm{Y}_{2} \mathrm{SiO}_{5}$ added sensitizers have the higher PL intensity. The PL intensity of the $\mathrm{X} 2-\mathrm{Y}_{2} \mathrm{SiO}_{5}: \mathrm{Ce} 1 \%: \mathrm{Li1} \%$ phosphor is $45 \%$ higher and the $\mathrm{X}_{2}-\mathrm{Y}_{2} \mathrm{SiO}_{5}: \mathrm{Ce} 1 \%: \mathrm{Na} 1 \%$ or $\mathrm{Y}_{2} \mathrm{SiO}_{5}: \mathrm{Ce} 1 \%: \mathrm{K} 1 \%$ is $20 \%$ 


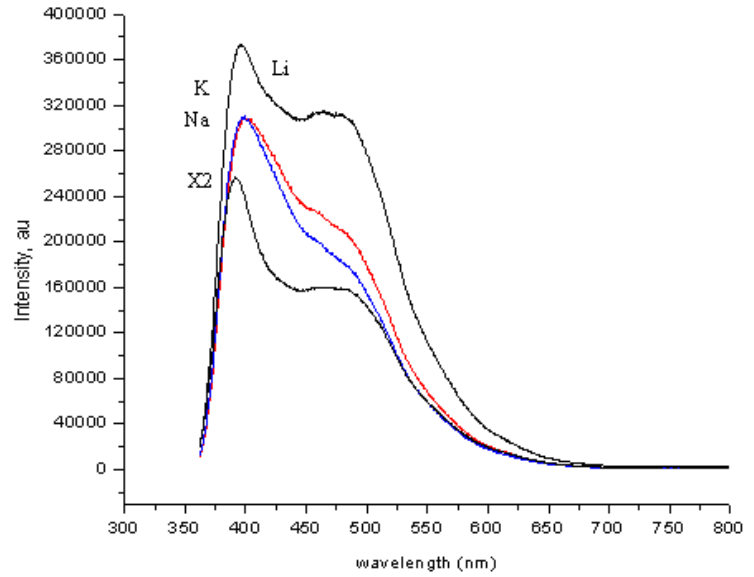

FIG. 10: Photoluminescence spectra of $\mathrm{X}_{2}-\mathrm{Y}_{2} \mathrm{SiO}_{5}: \mathrm{Ce} 1 \%$ :M1\% calcined at $1300^{\circ} \mathrm{C}, \mathrm{M}=\mathrm{Li}^{+}, \mathrm{Na}^{+}$and $\mathrm{K}^{+}$compared with $\mathrm{Y}_{2} \mathrm{SiO}_{5}$ : $\mathrm{Ce} 1 \%$ having no sensitizer $\left(\mathrm{X}_{2}-\mathrm{Y}_{2} \mathrm{SiO}_{5}\right)$. (a)

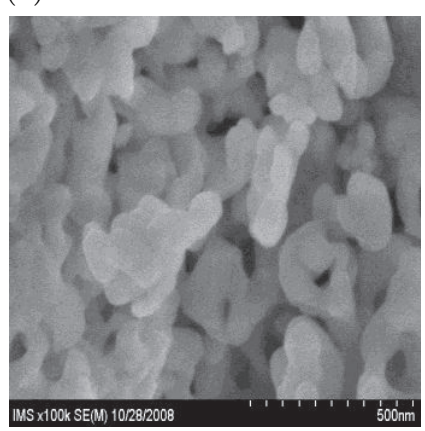

(b)

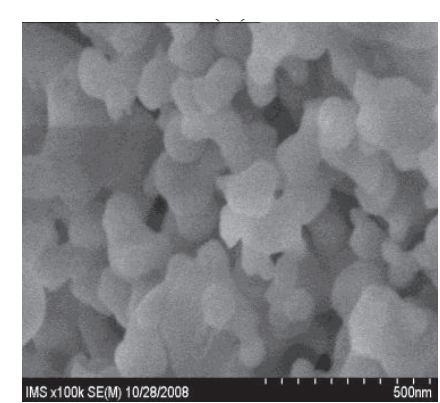

FIG. 11: SEM image of the (a) $\mathrm{X}_{1}-\mathrm{Y}_{2} \mathrm{SiO}_{5}$ and (b) $\mathrm{X}_{2}-\mathrm{Y}_{2} \mathrm{SiO}_{5}$ phosphors.

higher than that of the referenced $\mathrm{X}_{2}-\mathrm{Y}_{2} \mathrm{SiO}_{5}$. It indi- cates that $\mathrm{Li}^{+}, \mathrm{Na}^{+}$and $\mathrm{K}^{+}$ions are incorporated into the host crystal and the electroneutrality is ensured by the presence of a compensating valency elsewhere in the lattice.

\section{Morphology}

The morphology of the $\mathrm{X}_{1}-\mathrm{Y}_{2} \mathrm{SiO}_{5}$ and $\mathrm{X}_{2}-\mathrm{Y}_{2} \mathrm{SiO}_{5}$ phosphors was described in Fig. 11. $\mathrm{X}_{1}-\mathrm{Y}_{2} \mathrm{SiO}_{5}$ and $\mathrm{X}_{2^{-}}$ $\mathrm{Y}_{2} \mathrm{SiO}_{5}$ phosphors are of irregular shapes and compose of the agglomerates with particle size of approximately 70 $\mathrm{nm}$ to $100 \mathrm{~nm}$. It also indicates that the particle size of $\mathrm{X}_{2}-\mathrm{Y}_{2} \mathrm{SiO}_{5}$ phosphor seems larger than that of $\mathrm{X}_{1}$ $\mathrm{Y}_{2} \mathrm{SiO}_{5}$.

\section{CONCLUSION}

The examined sol-gel method is definitely suitable for the synthesis of pure-phase $\mathrm{X}_{1}-\mathrm{Y}_{2} \mathrm{SiO}_{5}$ or $\mathrm{X}_{2}-\mathrm{Y}_{2} \mathrm{SiO}_{5}$ and the beta or gamma- $\mathrm{Y}_{2} \mathrm{Si}_{2} \mathrm{O}_{7}$ phosphors when calcining the obtained precursor at $1100^{\circ} \mathrm{C}$ or $1300^{\circ} \mathrm{C}$ for an hour, respectively. When being excited by $\mathrm{UV}$ radiation at 325 $\mathrm{nm}$ wavelength, the blue light was emitted with the intensity increased strongly by adding $\mathrm{Li}, \mathrm{Na}$ or $\mathrm{K}$ sensitizers. The $\mathrm{X}_{1}-\mathrm{Y}_{2} \mathrm{SiO}_{5}$ and $\mathrm{X}_{2}-\mathrm{Y}_{2} \mathrm{SiO}_{5}$ phosphors are irregular shapes and compose of the agglomerates having particle size of approximately $70 \mathrm{~nm}$ to $100 \mathrm{~nm}$.

\section{Acknowledgments}

We wish to express our sincere thanks to Vietnam Ministry of Science and Technology for their financial support for the implementation of this research in the framework of KHCB 502606 project.
[1] K. A. Franz, R.-de Haen, A. G. Seelze, et al, in Ullmann's Encyclopedia of Industrial Chemistry, 7th Edition (Wiley$\mathrm{VCH}, 2004)$.

[2] N. Ralph, German patent DE10111909 (2002).

[3] P. J. Marsh, J. Silver, A. Vecht, and A. Newport, J. Luminescence 97, 229 (2002).

[4] P. D. Sarkisov, L. A. Orlova, N. V. Popovich, and Yu. E. Anan'eva, Glass and Ceramics 64, 3 (2007).

[5] L. Kepinski, M. Wołcyrz, Mater. Chem. Phys. 81, 396 (2003).

[6] C. Cannas, et al., Optical Mater. 29, 585 (2007).

[7] N. Karar and H. Chander, J. Phys. D. Appl. Phys. 38,
3580 (2005).

[8] T. Aitasalo, J. Holsa, M. Lastusaari, J. Niittykoski, and F. Pelle, Optical Mater. 27, 1511 (2005).

[9] T. Aitasalo, J. Holsa, M. Lastusaari, J. Legendziewicz ,J. Niittykoski, and F. Pell, Optical Mater. 26, 107 (2004).

[10] E.J. Bosze, J. McKittrick, and G. A. Hirata, Mater. Sci. Eng. B 97, 265 (2003).

[11] E. Coetsee, J. J. Terblans, and H. C. Swart, J. Luminescence 126, 37 (2007).

[12] X. Qin, Y. Ju, S. Bernhard, and N. Yao, Mater. Res. Bull. 42, 1440 (2007). 